\title{
Kontribusi intensitas komunikasi di media sosial Instagram terhadap citra tubuh remaja perempuan pelajar SMA di Denpasar
}

\author{
Ida Ayu Budha Brahmini dan Supriyadi \\ Program Studi Sarjana Psikologi, Fakultas Kedokteran, Universitas Udayana \\ paupasli@yahoo.com
}

\begin{abstract}
Abstrak
Citra tubuh adalah persepsi individu secara menyeluruh terhadap tubuhnya, yang meliputi pikiran, perasaan, dan perilaku terhadap tubuh yang dimilikinya. Penilaian tersebut tidak dapat dipisahkan dari faktor sosial, khususnya media. Melalui media remaja perempuan mengetahui informasi mengenai standar tubuh yang dianggap ideal di masyarakat. Beberapa tahun belakangan, media sosial berbasis gambar seperti Instagram menjadi alat komunikasi yang banyak digunakan oleh kalangan remaja perempuan. Penggunaan media sosial Instagram dapat ditinjau dari intensitas komunikasi antara pengguna media sosial tersebut. Penelitian ini bertujuan untuk mengetahui peran intensitas komunikasi di media sosial Instagram terhadap citra tubuh remaja perempuan dalam rentang usia 15-18 tahun di Denpasar. Pengambilan sampel dilakukan dengan teknik one stage cluster sampling. Responden yang digunakan dalam penelitian ini adalah remaja perempuan yang merupakan pengguna media sosial Instagram dari tiga Sekolah Menengah Atas Negeri (SMAN) Denpasar berjumlah 311 orang. Alat ukur yang digunakan dalam penelitian ini adalah skala intensitas komunikasi di media sosial Instagram dan skala citra tubuh. Hipotesis penelitian diuji dengan metode analisis regresi sederhana. Hasil penelitian menunjukkan bahwa terdapat hubungan yang berlawanan arah dan tingkat hubungan sedang antara intensitas komunikasi di media sosial Instagram terhadap citra tubuh remaja perempuan pelajar SMA di Denpasar $(\mathrm{R}=0,473 ; \mathrm{p}<0,05)$. Hasil tersebut menunjukkan bahwa semakin tinggi intensitas remaja perempuan dalam berkomunikasi di media sosial Instagram maka mengakibatkan semakin rendah citra tubuh yang dimilikinya. Koefisien determinasi $\left(\mathrm{R}^{2}\right)$ yang diperoleh dalam penelitian ini sebesar 0,224 dapat dimaknai bahwa sumbangan variabel intensitas komunikasi di media sosial Instagram dalam menjelaskan varian citra tubuh sebesar 22,4\%.
\end{abstract}

Kata kunci: Citra tubuh, Instagram, intensitas komunikasi, media sosial.

\begin{abstract}
Body image is the overall individual perception of the body, which includes thoughts, feelings, and behavior towards the body itself. The assessment can not be separated from social factors, especially the media. Through the media teenage girls know information about ideal standard of body in the community. In recent years, image-based social media such as Instagram has become a communication tool widely used by young women. The use of social media Instagram can be reviewed from the intensity of communication between users of social media. The aim of this study is to determine the role of communication intensity in social media Instagram on body image of female teenagers in the age 15-18 years in Denpasar. Sampling is done by one stage cluster sampling technique. The respondents used in this research are female teenager who is social media user of Instagram from three State High School (SMAN) Denpasar amounted to 311 sample. The measuring tool used in this research is scale of communication intensity in social media Instagram and body image scale. The research hypothesis was tested by simple regression analysis method. The results showed that there is an opposite relationship between the intensity of communication in social media Instagram on body image of high school girls in Denpasar $(R=0,473 ; p<0,05)$. These results indicate that the higher intensity of adolescent girls in communicating in social media Instagram hence result in lower body image. Coefficient of determination $\left(\mathrm{R}^{2}\right)$ obtained in this study amounted to 0,224 which can be interpreted that the contribution of communication intensity variables in social media Instagram in describing the varians of the body image $22,4 \%$.
\end{abstract}

Keywords: Body image, Instagram, intensity of communication, social media. 


\section{LATAR BELAKANG}

Masa remaja merupakan masa transisi antara masa kanakkanak dan masa dewasa, yang merupakan masa perkembangan yang dinamis, terjadi perubahan secara terus menerus pada seluruh aspek kehidupan remaja, yakni secara biologis, psikologis, kognitif dan sosio emosional. Menurut Santrock (2007), secara biologis, tubuh remaja mengalami berbagai perubahan, yang dikelompokkan menjadi perubahan fisik primer dan sekunder. Pada perubahan fisik primer, diawali dengan matangnya hormon seksual, pada remaja perempuan ditandai dengan menarche pertama yang terjadi mulai usia sembilan tahun. Remaja perempuan juga mengalami perubahan fisik sekunder seperti tinggi tubuh yang bertambah secara pesat, berat tubuh yang meningkat, pertumbuhan rambut-rambut halus di daerah sekitar kemaluan dan ketiak, membesarnya ukuran payudara, serta ukuran pinggul yang semakin melebar. Disisi lain, remaja juga semakin matang dalam berfikir dengan mengembangkan pemikiran yang abstrak, logis, dan dapat menilai bahwa dirinya berbeda dengan orang lain. Berdasarkan tahapan perkembangannya, masa remaja dibagi menjadi tiga kategori yakni remaja awal, remaja madya, dan remaja akhir.

Sarwono (2015) menyatakan bahwa perubahan fisik dianggap sebagai gejala primer pertumbuhan remaja, dan munculnya perubahan psikologis disebabkan oleh adanya perubahan fisik. Kepuasan terhadap tubuh dapat berdampak terhadap konsep diri dan harga diri selama remaja. Pada kenyataannya, banyak remaja yang merasa prihatin terhadap keadaan tubuhnya (Hurlock, 2002). Oleh karena itu, akibat berbagai perubahan yang terjadi di tubuhnya, dan segala informasi yang diterima mengenai tubuh, menjadikan remaja semakin memperhatikan tubuh dan membuat penilaian yang mengarah pada perilaku untuk beradaptasi dengan keadaan tersebut.

Pelajar Sekolah Menengah Atas (SMA) pada umumnya berada dikisaran usia 15-18 tahun (Said, 2015). Individu yang berada pada rentang usia tersebut digolongkan ke dalam remaja madya (Lerner \& Steinberg, 2002). Karakteristik seseorang yang berada pada tahap perkembangan remaja madya adalah perubahan fisik yang hampir menyerupai orang dewasa (Said, 2015), dan merasa senang saat berkumpul bersama dengan teman sebaya (Sarwono, 2015). Selain itu, berdasarkan pada tugas perkembangannya (Hurlock, 2002) remaja diharapkan untuk menerima keadaan fisiknya dan memanfaatkannya secara efektif. Pada remaja perempuan ditingkat Sekolah Menengah Atas, perubahan fisik sudah tidak banyak terjadi dan individu sudah mulai mengatasi permasalahan tersebut dengan mencari informasi dari lingkungan sekitarnya. Perbincangan seputar tubuh menjadi topik yang umumnya dibahas saat remaja perempuan bersama dengan temantemannya, selain itu remaja perempuan saling membandingkan penampilan satu sama lainnya (Cash, 2012).
Menurut Peraturan Pemerintah Republik Indoneisa Nomor 17 Tahun 2010 tentang Pengelolaan dan Penyelenggaraan Pendidikan, Sekolah Menengah Atas (SMA) adalah pendidikan menengah yang merupakan lanjutan dari tingkat pendidikan Sekolah Menengah Pertama (SMP), Madrasah Tsanawiyah (MTs), atau bentuk pendidikan lain yang sederajat dan lanjutan yang diakui atau setara SMP atau MTs. SMA diselenggarakan oleh pemerintah maupun swasta, pada SMA Negeri bersifat umum dan tidak terdapat batasan agama dan budaya, hal tersebut tercermin dalam peraturan sekolah yang berlaku yang mengacu pada peraturan pemerintah.

Seluruh pengalaman manusia yang meliputi persepsi, emosi, dan perilaku yang berkaitan dengan tubuh dikenal sebagai citra tubuh (Cash \& Pruzinsky, 2002). Perubahan penilaian remaja terhadap tubuhnya sangat ditentukan oleh pengalaman sosial yang dimiliki. Hal tersebut membuktikan bahwa citra tubuh memiliki sifat yang dapat berubah dan terbuka terhadap berbagai informasi baru (Grogan, 2008). Lingkungan sosial berperan secara signifikan terhadap keyakinan remaja akan standar penampilan ideal yang hendak dimilikinya. Informasi mengenai tubuh disebarkan secara meluas melalui media seperti koran, majalah, televisi, hingga situs internet. Selain media, keluarga dan teman sebaya merupakan referensi utama bagi remaja untuk mendapatkan informasi yang relevan mengenai cara berpenampilan (Grogan, 2008).

Media menyampaikan informasi mengenai tubuh yang kurus sebagai bentuk tubuh ideal untuk dimiliki oleh seseorang, setelah menerima informasi tersebut remaja cenderung berkeinginan untuk memiliki tubuh yang kurus (Dittmar, 2009). Pada kenyataannya, acara televisi, seperti pemilihan putri kecantikan, remaja yang dapat mengikuti ajang tersebut adalah remaja perempuan yang memiliki penampilan menarik dan cantik dengan tinggi badan sesuai yang telah ditetapkan. Secara tidak langsung menampilkan bahwa bentuk tubuh ideal yang dimiliki oleh remaja perempuan adalah bentuk tubuh yang tinggi dan ramping. Perasaan tidak puas terhadap tubuh timbul karena remaja perempuan lebih banyak menginternalisasi informasi yang diperoleh dari lingkungan sosial (Brennan, 2010).

Internalisasi adalah proses individu menjadikan nilai-nilai dari luar dirinya sebagai pengganti nilai-nilai pribadinya terhadap diri dan tubuh yang dimiliki (Cash \& Pruzinsky, 2002). Informasi dari lingkungan sosial mengenai tubuh diperoleh remaja perempuan secara verbal maupun nonverbal, dalam bentuk kata-kata dan perilaku. Remaja perempuan menjadikan nilai yang dianggap ideal oleh lingkungannya sebagai nilai pribadinya. Hal ini mempengaruhi penilaian remaja terhadap keadaan fisik yang dimiliki, apabila lingkungan memberikan komentar negatif, maka remaja perempuan cenderung untuk meyakini dan beranggapan bahwa tubuh yang dimilikinya kurang menarik. Berdasarkan hasil studi pendahuluan (Brahmini, 2017), dinyatakan bahwa reaksi yang diberikan oleh lingkungan 
terhadap penampilan fisik remaja perempuan mempengaruhi penilaian remaja terhadap tubuhnya. Saat mendapatkan komentar yang negatif, remaja cenderung merasa kurang puas terhadap keadaan fisiknya sehingga menimbulkan perasaan tidak percaya diri pada diri remaja. Selain itu, kekhawatiran terhadap penilaian yang diberikan oleh orang lain akan tubuhnya menyebabkan remaja perempuan lebih berhati-hati dalam memilih pakaian yang digunakannya.

Beberapa gambar di media menyebabkan remaja perempuan melihat dirinya sendiri layaknya objek yang dapat dikagumi dan dikritik oleh orang lain (Grogan, 2008). Berdasarkan hasil wawancara yang dilakukan dengan salah satu subjek (Brahmini, 2017) ditunjukkan bahwa sebelum mengunggah foto ke media sosial Instagram, subjek mengedit foto agar terlihat lebih menarik. Selain itu, subjek juga bertanya pendapat teman mengenai foto yang akan diunggahnya. Hal itu dilakukan subjek karena ia merasa khawatir dengan komentar yang akan diberikan oleh orang lain terhadap penampilannya dalam foto tersebut. Cash dan Smolak (2011) menyatakan bahwa beberapa tahun belakangan internet berpengaruh terhadap penilaian remaja akan penampilan fisiknya. Semakin berkembangnya akses internet, memberikan kemudahan bagi remaja perempuan untuk memenuhi kebutuhannya dalam memperoleh informasi mengenai tubuh secara cepat dan meluas. Berdasarkan pada studi pendahuluan (Brahmini, 2017) ditunjukkan bahwa remaja perempuan membandingkan tubuhnya dengan milik orang lain seperti artis, teman sebaya, hingga orang lain yang tidak dikenalnya di media sosial Instagram. Perbandingan tersebut menyebabkan remaja perempuan merasa tidak puas terhadap keadaan fisiknya dan berupaya untuk mengatasi permasalahan tersebut dengan menggunakan perias wajah, melakukan olahraga, dan mengatur makanan yang dikonsumsi setiap harinya. Berdasarkan observasi pada studi pendahuluan (Brahmini, 2017) terlihat bahwa remaja perempuan yang bersekolah di SMA Negeri di Denpasar menggunakan perias wajah seperti pemerah pipi, pewarna bibir, bulu mata palsu, pensil alis, dan juga bedak, saat datang ke sekolah.

Seiring dengan perkembangan internet yang cukup pesat di Indonesia, menurut data yang dirilis tahun 2017 oleh Kementrian Komunikasi dan Informatika Republik Indonesia dinyatakan bahwa pengguna internet di Indonesia mencapai 132 juta orang, dan 95\% dari angka tersebut memanfaatkan internet untuk mengakses media sosial (Diandra, 2017). Sehingga berdasarkan pada data yang telah ditunjukkan, maka media sosial merupakan salah satu saluran komunikasi yang digemari di lingkungan masyarakat, tidak terkecuali remaja perempuan. Saat ini, internet sudah menjadi sesuatu yang lazim bagi remaja di wilayah perkotaan, tidak terkecuali bagi remaja perempuan di Denpasar. Di wilayah perkotaan seperti Denpasar, banyak remaja perempuan yang memiliki gawai dan juga telah didukung oleh adanya infrastruktur untuk mengakses internet yang memadai.

Dalam gawai tersedia berbagai aplikasi media sosial, selama remaja perempuan terhubung dengan koneksi internet, maka ia dapat mengakses media sosial tanpa ada batasan waktu.
Media sosial memiliki karakteristik yang membedakannya dari media lainnya, yakni adanya komunikasi, partisipasi, dan keterbukaan dalam menyampaikan pendapat (Mayfield, 2008). Sehingga, penggunaan media sosial dapat didasarkan pada intensitas komunikasi yang dilakukan oleh individu dalam media sosial. Intensitas komunikasi dapat ditinjau dari frekuensi, durasi, perhatian yang diberikan dalam berkomunikasi, keteraturan seseorang dalam melakukan komunikasi, tingkat keluasan pesan serta jumlah orang yang terlibat dalam proses berkomunikasi (Devito, 2009).

Salah satu jejaring sosial yang saat ini diminati oleh remaja adalah Instagram. Media sosial Instagram mendorong penggunanya untuk saling berinteraksi dan berpartisipasi melalui fitur-fitur yang disediakan, seperti menggunggah foto ataupun video, menyukai (like) kiriman pengguna lain, mengomentari foto, melakukan siaran langsung, dan juga dapat saling mengirimkan pesan. Segala fitur yang disediakan oleh media sosial Instagram memberikan kemudahan bagi penggunanya untuk berkomunikasi dan menampilkan diri kepada orang lain. Disisi lain, media sosial Instagram juga memberikan dampak negatif bagi penggunanya seperti persaingan hidup mewah, krisis percaya diri, dan tidak mau menatap realita dan kenyataan (Mahardika, 2015).

Media terkadang menyediakan informasi mengenai bentuk tubuh yang tidak sehat dan remaja perempuan terdorong untuk mengadopsi informasi tersebut dengan melakukan diet yang tidak sehat (Dewi, 2015). Fardouly, Diedrichs, Vartanian, dan Halliwel (2015) mengungkapkan bahwa penggunaan Facebook dapat meningkatkan mood negatif penggunanya, dan berdasarkan dari penelitian yang tersebut juga ditemukan bahwa individu yang menggunakan lebih banyak waktu untuk mengakses Facebook memiliki keinginan yang lebih besar untuk melakukan perubahan pada area tubuh seperti wajah, rambut, dan kulit.

Levine dan Smolak (dalam Cash \& Smolak, 2002) menjelaskan bahwa remaja memanfaatkan media seperti majalah dan televisi untuk mendapatkan informasi guna membantu mereka dalam menemukan definisi dan memperoleh bentuk tubuh yang sesuai, serta meningkatkan kepuasan terhadap tubuh yang dimilikinya. Ketidakpuasan terhadap tubuh yang pada awalnya disebabkan oleh media tradisional seperti majalah, iklan, dan lain sebagainya, dapat juga terjadi oleh media baru, khususnya media sosial (Perloff, 2014). Informasi dari internet dan majalah berkorelasi dengan internalisasi mengenai tubuh yang kurus, perbandingan penampilan, motivasi untuk menjadi kurus, serta perasaan tidak puas terhadap berat badan yang dimiliki (Tiggeman \& Miller, 2010).

Fardouly, Pinkus, dan Vartanian (2017) menyatakan bahwa pengguna media sosial Instagram, khususnya pada remaja perempuan, melakukan perbandingan terhadap tubuh yang dimilikinya dengan milik orang lain, perbandingan tersebut menimbulkan perasaan tidak puas terhadap tubuh. Ketidakpuasan tersebut menyebabkan remaja perempuan menjadi lebih selektif dalam memilih foto maupun video serta mengedit foto agar tampak lebih menarik sebelum nantinya diunggah di media sosial Instagram. Hasil serupa juga ditunjukkan oleh Manago, Graham, Greenfield, dan 
Salimkhan (2008) dalam penelitiannya menunjukkan bahwa individu sering kali mengunggah foto yang terlihat menarik dan juga langsing di media sosial.

Semakin banyak waktu yang digunakan untuk mengakses media sosial, menimbulkan keinginan remaja perempuan untuk terlihat lebih menarik, mengubah penampilan, serta menurunkan berat badan (Endresz \& Pepin, 2015). Tidak jarang, untuk mendapatkan tubuh yang dianggap ideal, remaja perempuan menerapkan pola hidup yang tidak sehat, seperti melakukan diet dan olahraga secara berlebihan yang nantinya dapat berdampak buruk bagi kesehatan mereka.

Wertheim dan Paxton (dalam Cash, 2012) menyatakan bahwa apabila aktivitas komunikasi di media sosial semakin interaktif maka hal tersebut dapat memberikan dampak bagi penilaian remaja perempuan terhadap keadaan fisiknya. Berdasarkan hasil wawancara dengan subjek (Brahmini, 2017), dinyatakan bahwa setelah melihat foto-foto teman sebaya di media sosial Instagram subjek merasa tidak puas dengan penampilan yang dimiliki saat ini. Hasil serupa turut ditemukan, berdasarkan pada hasil wawancara terhadap subjek lainnya yang menyatakan bahwa semakin sering dirinya melihat foto artis-artis di media sosial Instagram, subjek merasa memiliki berat badan yang berlebih dan menimbulkan keinginannya untuk menurunkan berat badan. Selain itu, subjek juga merasa ingin memiliki penampilan seperti artis yang diidolakannya di media sosial Instagram.

Cramer dan Inkster (2017) menyatakan bahwa Instagram merupakan media sosial yang paling memberikan dampak buruk bagi kesehatan mental remaja. Penelitian yang dilakukan terhadap 1.500 orang remaja di Inggris ini, turut mengungkapkan bahwa penggunaan media sosial dapat berdampak negatif, seperti meningkatkan rasa cemas, menimbulkan depresi, memperburuk citra tubuh, menimbulkan cyberbullying, dan fear of missing out. Selain itu, berdasarkan survey tersebut, dinyatakan bahwa setengah dari sampel penelitian yang berusia 14-24 tahun mengungkapkan penggunaan Instagram dan Facebook dapat meningkatkan perasaan cemas. Sebanyak $70 \%$ remaja dalam penelitian tersebut mengatakan bahwa Instagram memperburuk penilaian remaja terhadap tubuhnya.

Melalui media sosial Instagram, remaja perempuan menerima informasi dalam bentuk visual sehingga memudahkan mereka untuk memperoleh gambaran mengenai standar tubuh yang dianggap ideal di masyarakat. Didukung dengan kemudahan untuk mengakses media sosial, memberikan kesempatan bagi remaja perempuan untuk memperoleh informasi mengenai tubuh menjadi semakin meluas. Perilaku remaja perempuan yang menggunakan sebagian besar waktunya untuk mengakses media sosial, menyebabkan keterpaparan secara terus menerus terhadap informasi mengenai tubuh yang dianggap ideal. Apabila berbagai informasi diterima, namun jika tidak disertai dengan filterisasi yang tepat, dapat berdampak pada timbulnya perasaan tidak puas dalam diri remaja perempuan terhadap tubuhnya. Dikhawatirkan, ketidakpuasan tersebut mendorong perilaku remaja perempuan untuk melakukan cara-cara yang tidak sehat untuk memperoleh bentuk tubuh yang ideal. Berdasarkan dari permasalahan tersebut, perlu dilakukan penelitian yang bertujuan untuk mengetahui bagaimana kontribusi intensitas komunikasi media sosial, khususnya Instagram, terhadap citra tubuh remaja pelajar perempuan di Denpasar.

Adapun tujuan dari penelitian ini adalah untuk mengetahui seberapa besar kontribusi komunikasi media sosial Instagram terhadap citra tubuh remaja perempuan pelajar SMA Negeri di Denpasar. Dengan demikian, maka dapat ditarik hipotesis dalam penelitian ini yaitu pertama, hipotesis nol adalah tidak terdapat kontribusi intensitas komunikasi di media sosial Instagram terhadap citra tubuh remaja putri pelajar Sekolah Menengah Atas di Denpasar. Kedua, hipotesis alternatif adalah terdapat kontribusi intensitas komunikasi di media sosial Instagram terhadap citra tubuh remaja putri pelajar Sekolah Menengah Atas di Denpasar.

\section{METODE PENELITIAN}

\section{Variabel dan Definisi Operasional}

Variabel bebas dalam penelitian ini adalah intensitas komunikasi di media sosial Instagram serta variabel tergantung dalam penelitian ini adalah citra tubuh. Adapun definisi operasional dari masing-masing variabel dalam penelitian ini adalah sebagai berikut:

Intensitas Komunikasi di Media Sosial Instagram

Intensitas komunikasi di media sosial Instagram adalah tingkat kedalaman dan kekuatan sikap seseorang dalam berkomunikasi di media sosial Instagram. Intensitas komunikasi di media sosial Instagram dalam penelitian ini diukur dengan skala psikologis menggunakan aspek intensitas komunikasi menurut Devito (2009). Semakin tinggi skor total yang diperoleh maka semakin tinggi intensitas komunikasinya.

Citra Tubuh

Citra tubuh adalah penilaian individu secara menyeluruh terhadap tubuhnya, yang berpengaruh terhadap kognitif, perasaan, dan tingkah laku. Citra tubuh dalam penelitian ini diukur menggunakan aspek citra tubuh menurut Davidson dan McCabe (2006). Semakin tinggi skor total yang diperoleh maka semakin tinggi citra tubuhnya.

\section{Responden}

Populasi dalam penelitian ini adalah remaja perempuan yang berusia 15-18 tahun dan merupakan pelajar dari Sekolah Menengah Atas (SMA) Negeri di Denpasar, serta memiliki akun media sosial Instagram. Sampel dalam penelitian ini memiliki karakteristik yaitu berjenis kelamin perempuan, mmiliki akun media sosial Instagram, berada pada rentang usia 15-18 tahun, bersekolah di SMA Negeri di Denpasar.

Teknik pengambilan sampel yang digunakan dalam penelitian ini adalah teknik cluster random sampling yang termasuk salah satu jenis probabaility random sampling. Cluster random sampling atau teknik sampling daerah, didefinisikan sebagai cara yang digunakan dalam mengambil sampel berdasarkan dari daerah populasi yang telah ditetapkan (Sugiyono, 2016). Jenis cluster sampling yang digunakan adalah pendekatan one stage cluster sampling. Pengambilan sampel perlu mempertimbangkan ukuran sampel atau jumlah anggota sampel yang digunakan. Field (2009) menyatakan bahwa jumlah sampel yang 
digunakan dalam sebuah penelitian dapat diukur berdasarkan jumlah variabel yang ada, jika menggunakan analisis regresi pada setiap variabelnya diperlukan 10 hingga 15 responden. Dalam penelitian ini jumlah variabel yang digunakan adalah sebanyak dua buah, yakni intensitas komunikasi di media sosial Instagram sebagai variabel bebas, dan citra tubuh sebagai variabel tergantung, maka jumlah responden minimal pada setiap variabel sebanyak 15 responden. Sehingga berdasarkan pada hasil perhitungan tersebut, sampel yang diperlukan dalam penelitian ini minimal sebanyak 30 responden.

\section{Tempat Penelitian}

Pelaksanaan penelitian dilakukan pada bulan Januari. Pada tanggal 4 Januari 2018 di SMA Negeri 2 Denpasar, pada tanggal 10 Januari 2018 di SMA Negeri 1 Denpasar, dan pada tanggal 11 Januari 2018 di SMA Negeri 7 Denpasar. Jumlah kuesioner yang disebar sebanyak 320 kuesioner, namun jumlah yang kembali dan memenuhi syarat untuk dapat dianalisis sebanyak 311 kuesioner. Dengan demikian sampel yang digunakan dalam penelitian ini adalah 311 remaja perempuan pelajar SMA Negeri di Denpasar yang berusia 15-18 tahun dan memiliki media sosial Instagram

\section{Alat Ukur}

Alat ukur dalam penelitian ini menggunakan dua skala psikologi, yaitu Skala Intensitas Komunikasi di Media Sosial Instagram dan Skala Citra Tubuh. Skala Intensitas Komunikasi di Media Sosial Instagram disusun berdasarkan enam aspek intensitas komunikasi dari Devito (2009), Skala Citra Tubuh disusun berdasarkan tujuh aspek citra tubuh dari Davidson dan McCabe (2006). Skala Intensitas Komunikasi di Media Sosial Instagram terdiri dari 30 aitem, Skala Citra Tubuh terdiri dari 32 aitem. Setiap aitem disusun menjadi aitem yang favorable dan unfavorable dengan empat pilihan jawaban yaitu sangat setuju (SS), setuju (S), tidak setuju (TS), dan sangat tidak setuju (STS).

Sebelum melakukan pengambilan data penelitian maka dilakukan uji validitas dan uji reliabilitas alat ukur yang akan dipakai pada penelitian. Pengujian validitas isi dalam penelitian ini dilakukan dengan menggunakan expert judgment oleh dua orang ahli di bidang Psikologi Sosial dan Psikologi Perkembangan. Pengujian validitas konstrak dilakukan dengan melihat nilai korelasi aitem total yang terkoreksi, apabila lebih besar sama dengan 0,25 maka aitem dikatakan telah valid (Azwar, 2015b). Pengujian reliabilitas dalam penelitian ini menggunakan formula Cronbach's Alpha untuk skala intensitas komunikasi di media sosial Instagram dan formula skor komposit Mosier untuk skala citra tubuh. Suatu aitem yang memiliki nilai koefisien reliabilitas di atas 0,6 telah dikatakan baik dan reliabel (Azwar, 2015b).

Hasil uji validitas Intensitas Komunikasi di Media Sosial Instagram memiliki koefisien korelasi aitem total yang terkoreksi berkisar pada rentang 0,314 sampai 0,670. Hasil uji reliabilitas menunjukkan koefisien Alpha $(\alpha)$ sebesar 0,706 yang berarti bahwa Skala Intensitas Komunikasi di Media Sosial Instagram mampu mencerminkan 70,6\% variasi skor murni responden. Hasil uji validitas Skala Citra Tubuh memiliki koefisien korelasi aitem total yang terkoreksi berkisar pada rentang 0,257 sampai 0,611. Hasil perhitungan skor komposit dengan formula Mosier didapatkan reliabilitas Skala Citra Tubuh sebesar 0,843, yang berarti bahwa Skala Citra Tubuh mampu mencerminkan $84,3 \%$ variasi skor murni responden.

\section{Teknik Analisis Data}

Uji asumsi dalam penelitian ini menggunakan uji normalitas dengan formuluasi One Sample T-Test dengan teknik Kolmogorov-Smirnov, dan uji linieritas dengan Ramsey Test. Uji hipotesis dilakukan dengan menggunakan uji regresi sederhana. Uji ini digunakan untuk memprediksi suatu hubungan antara satu variabel bebas dengan satu variabel tergantung (Santoso, 2014).

\section{HASIL PENELITIAN}

\section{Karakteristik Subjek}

Responden dalam penelitian ini adalah 311 orang remaja perempuan berusia 15-18 tahun yang merupakan pelajar SMA Negeri di Denpasar dan memiliki media sosial Instagram. Apabila dilihat berdasarkan usia, mayoritas responden berusia 16 tahun dengan prosentase sebesar $45,7 \%$.

\section{Deskripsi Data Penelitian}

Hasil deskripsi penelitian variabel intensitas komunikasi di media sosial Instagram dan citra tubuh dapat dilihat pada tabel 1 (terlampir). Hasil deskripsi statistik pada tabel 1 berdasarkan pengujian One Sampel T-Test, ditunjukkan bahwa pada skala intensitas komunikasi di media sosial Instagram, skor terendah yang didapatkan subjek sebesar 48 dan skor tertinggi sebesar 102, secara teoretis sebaran skor berada pada rentang 30 hingga 120. Mean empiris pada skala intensitas komunikasi di media sosial Instagram sebesar 72,91 dengan standar deviasi empiris sebesar 8,584 dan mean teoretis sebesar 75 dengan standar deviasi teoretis sebesar 15. Hasil perbandingan antara mean empiris dan mean teoretis menunjukkan bahwa mean empiris lebih kecil dari mean teoretis. Sehingga dapat diartikan subjek dalam penelitian ini memiliki intensitas komunikasi di media sosial Instagram yang rendah jika dibandingkan dengan populasi.

Sementara itu, pada skala citra tubuh ditunjukkan bahwa sebaran skor secara teoretik berada pada rentang 32 hingga 128. Namun berdasarkan pada skor yang didapatkan oleh subjek penelitian, skor terendah yang didapat subjek sebesar 48 dan yang tertinggi sebesar 110. Mean empiris pada skala citra tubuh sebesar 72,91 dengan standar deviasi 8,537 lebih kecil jika dibandingkan dengan mean teoretisnya yaitu 80 dengan standar deviasi teoretis sebesar 16. Dengan demikian dapat diartikan bahwa subjek dalam penelitian ini memiliki citra tubuh yang rendah dibandingkan dengan populasi.

\section{Uji Asumsi}

Uji normalitas dilakukan dengan formulasi One Sample TTest dengan teknik Kolmogorov-Smirnov. Apabila taraf signifikansi lebih besar dari $0,05(\mathrm{p}>0,05)$, maka data dikatakan berdistribusi normal (Santoso, 2014). Berdasarkan tabel 2 (terlampir), taraf signifikansi variabel intensitas komunikasi di media sosial Instagram sebesar 0,258 $(\mathrm{p}>0,05)$, dan taraf signifikansi variabel citra tubuh sebesar 
$0,096$ ( $\mathrm{p}>0,05)$, sehingga disimpulkan bahwa data pada kedua variabel berdistribusi normal.

Linieritas dalam penelitian ini diuji dengan menggunakan teknik Ramsey Test mengacu pada (Ghozali, 2016). Berdasarkan dari hasil perhitungan yang telah dilakukan, ditunjukkan bahwa nilai F-hitung sebesar 0,058. Untuk mengetahui model regresi dalam bentuk linear, F-hitung selanjutnya dibandingkan dengan F-tabel, nilai F-tabel dengan degree of freedom $(\mathrm{df})=(\mathrm{n}-\mathrm{k})=308$ dan jumlah parameter 2 adalah 3,03. Sehingga, hasil perbandingan antara F-hitung dengan F-tabel menunjukkan F-hitung lebih kecil dari F-tabel, yang memiliki arti model regresi dalam bentuk yang linear (terlampir).

\section{Uji Hipotesis}

Hasil uji regresi berganda variabel intensitas komunikasi di media sosial Instagram dan citra tubuh adalah sebagai berikut (tabel terlampir) Uji hipotesis dalam penelitian ini menggunakan teknik analisis regresi sederhana. Uji regresi berganda bertujuan untuk memprediksi suatu hubungan antara satu variabel bebas dengan variabel tergantung (Santoso, 2014). Berdasarkan tabel 4 (terlampir) diperoleh taraf signifikansi sebesar $0.000 \quad(\mathrm{p}<0.05)$. Hal tersebut menunjukkan bahwa variabel intensitas komunikasi di media sosial Instagram dapat digunakan untuk memprediksi citra tubuh.

Berdasarkan tabel 5 (terlampir) diperoleh nilai $\mathrm{R}$ sebesar 0,473 , dengan koefisien beta $-0,471$. Hal ini menunjukkan terdapat hubungan negatif antara variabel intensitas komunikasi di media sosial Instagram terhadap variabel citra tubuh. Berdasarkan tabel 5, diperoleh juga nilai koefisien determinasi sebesar 0,224. Hal ini menunjukkan besaran peran dari variabel intensitas komunikasi di media sosial Instagram yaitu sebesar $22,4 \%$.

Berdasarkan tabel 6 (terlampir), intensitas komunikasi di media sosial Instagram memiliki koefisien beta terstandarisasi sebesar $-0,471$, nilai t sebesar $-9,441$, dan signifikansi 0,000 $(\mathrm{p}<0,05)$, sehingga intensitas komunikasi di media sosial Instagram berperan secara signifikan terhadap citra tubuh remaja perempuan pelajar SMA Negeri di Denpasar. Koefisien regresi (B) bernilai negatif bermakna bahwa kedua variabel berkorelasi secara negatif, artinya kenaikan intensitas komunikasi di media sosial Instagram akan mengakibatkan penurunan citra tubuh. Berdasarkan tabel 6, hasil uji regresi sederhana dapat memprediksi taraf kecenderungan citra tubuh dari masing-masing responden dengan melihat persamaan garis regresi sebagai berikut:

$\mathrm{Y}=40,690+(-0,471) \mathrm{X}$

Keterangan:

Y: Kecenderungan citra tubuh

$\mathrm{X}$ : Intensitas komunikasi di media sosial Instagram

Persamaan garis regresi tersebut memiliki arti sebagai berikut:

a. Konstanta sebesar 40,690 menyatakan bahwa jika tidak ada penambahan atau peningkatan skor pada variabel intensitas komunikasi di media sosial
Instagram, maka taraf kecenderungan citra tubuh sebesar 40,690.

b. Koefisien regresi sebesar $-0,471$ menyatakan bahwa setiap penambahan atau peningkatan satuan

nilai responden pada variabel intensitas komunikasi di media sosial Instagram, maka akan terjadi penurunan pada penilaian citra tubuh sebesar 0,471 .

Rangkuman hasil uji hipotesis dalam penelitian ini dapat dilihat pada tabel 7 (terlampir).

\section{PEMBAHASAN DAN KESIMPULAN}

Berdasarkan hasil analisis regresi sederhana ditunjukkan bahwa adanya hubungan yang negatif dan signifikan antara intensitas komunikasi di media sosial Instagram dengan citra tubuh pada remaja putri pelajar SMA di Denpasar. Hal ini dibuktikan dari koefisien regresi (B) sebesar -0,471, nilai F tabel sebesar 89,133, dengan tingkat signifikansi sebesar 0,000 . Koefisien determinasi sebesar 0,224 yang memiliki makna intensitas komunikasi di media sosial Instagram memberikan kontribusi sebanyak $22,4 \%$ terhadap citra tubuh. Sedangkan masih ada $77,6 \%$ faktor lain yang berperan terhadap citra tubuh remaja putri pelajar SMA di Denpasar.

Koefisien korelasi antara kedua variabel tersebut sebesar 0,473 . Berdasarkan pada tabel interpretasi koefisien korelasi dalam Sugiyono (2016) dinyatakan bahwa koefisien korelasi yang berada pada interval korelasi 0,40-0,599 dikategorikan memiliki tingkat hubungan yang sedang. Dengan demikian hipotesis penelitian dapat diterima yaitu adanya kontribusi intensitas komunikasi di media sosial Instagram terhadap citra tubuh

Hasil analisis koefisien beta terstandarisasi dari intensitas komunikasi di media sosial Instagram menunjukkan nilai sebesar -0,471, nilai $\mathrm{t}$ sebesar -9,441, dengan tingkat signifikansi sebesar $0,000 \quad(\mathrm{p}<0,05)$, yang bermakna intensitas komunikasi di media sosial Instagram berperan secara signifikan terhadap citra tubuh remaja putri pelajar SMA di Denpasar. Sehingga hasil tersebut sejalan dengan pemaparan Cash dan Pruzinsky (2002) yang menyatakan bahwa berdasarkan faktor sosiokultural, media memberikan pengaruh bagi penilaian remaja perempuan terhadap tubuhnya.

Media menyalurkan informasi mengenai standar tubuh yang dianggap ideal di masyarakat (Cash \& Pruzinsky, 2002). Saat ini, budaya komunikasi di masyarakat tengah mengalami pergeseran dari era konvensional ke era modern, yakni dari komunikasi tatap muka menjadi computer mediate communication (Utami, Lestari, \& Putra, 2015). Sehingga tidak dapat dipungkiri, ketidakpuasan perempuan terhadap tubuhnya yang dahulu disebabkan oleh media konvensional, dapat juga disebabkan oleh media sosial (Perloff, 2014). Didukung juga oleh Cash dan Smolak (2011) yang menyatakan bahwa beberapa tahun belakangan, internet menjadi salah satu penyalur informasi mengenai standar tubuh yang ideal diterima oleh masyarakat.

Hasil penelitian ini memperkuat penelitian yang telah dilakukan sebelumnya, yang menyatakan bahwa intensitas 


\section{I.A.B. BRAHMINI \& SUPRIYADI}

mengakses internet, khususnya media sosial, menjadi salah satu faktor sosial budaya yang memiliki hubungan yang kuat dengan citra tubuh remaja perempuan (Tiggemann \& Slatter, 2013). Selanjutnya, hasil yang serupa juga ditemukan oleh Vriess, Peter, Graaf, dan Nikken (2015) menyatakan bahwa semakin tinggi intensitas seseorang dalam mengakses media sosial berkaitan dengan meningkatnya perasaan tidak puas terhadap tubuh. Hal tersebut ditunjukkan dengan timbulnya keinginan remaja untuk tampil lebih menarik, sehingga mereka cenderung untuk melakukan perubahan pada penampilan dan berupaya untuk menurunkan berat badan.

Penelitian ini juga didukung oleh hasil penelitian yang dilakukan oleh Fardouly, Diedrichs, Vartarnian, Halliwel (2015), dibuktikan bahwa remaja perempuan yang menggunakan lebih banyak waktu untuk mengakses media sosial Facebook memiliki keinginan yang lebih besar untuk melakukan perubahan terhadap penampilannya. Tiggeman dan Miller (2010) menyatakan bahwa informasi dari internet dan majalah berkorelasi dengan internalisasi tubuh yang kurus, perbandingan penampilan, dan motivasi untuk menjadi kurus, serta perasaan tidak puas terhadap berat badan yang dimiliki.

Dalam penelitian saat ini, dibuktikan dari nilai koefisien regresi sebesar $-0,471$, dan memiliki arah hubungan yang negatif, dengan demikian semakin tinggi intensitas remaja perempuan dalam mengakses media sosial Instagram maka semakin rendah citra tubuh remaja. Hasil tersebut dapat disebabkan karena melihat foto selebritis dan teman sebaya di media sosial Instagram berkaitan dengan meningkatnya ketidakpuasan perempuan terhadap penampilan fisiknya (Brown \& Tiggeman, 2016). Perasaan tidak puas terhadap tubuh disebabkan karena perempuan melakukan upward social comparisons terhadap foto yang mereka lihat di media sosial Instagram dan Facebook (Behan, 2015). Kleemans, Daalmans, Carbaat, dan Anschut (2016) juga menyatakan bahwa remaja perempuan dengan kecenderungan tinggi untuk membandingkan diri sendiri dengan orang lain dilaporkan memiliki citra tubuh yang lebih rendah, terlebih setelah melihat foto teman sebaya maupun orang lain yang tidak dikenalnya di media sosial Instagram.

Perbandingan sosial adalah evaluasi yang dilakukan oleh seseorang terhadap dirinya sendiri (Festinger, 1954). Perbandingan sosial dibagi menjadi dua yakni upward social comparisons serta downward social comparisons. Remaja perempuan merasa tidak puas terhadap tubuhnya setelah melakukan upward social comparisons, dikarenakan remaja perempuan membandingkan ciri maupun kemampuannya dengan milik orang lain yang lebih dari dirinya. Apabila remaja perempuan membandingkan diri dengan orang yang lebih lemah dari dirinya, maka dapat meningkatkan perasaan puas terhadap keadaan fisik yang dimiliki (Taylor, Peplau, Sears, 2009).

Informasi dalam media sosial Instagram disampaikan melalui konten visual, seperti foto dan video. Remaja perempuan pengguna media sosial Instagram dapat dengan mudah menginternalisasi informasi mengenai penampilan tubuh dari media tersebut, dikarenakan berdasarkan teori picture superiority, dinyatakan bahwa manusia lebih mudah untuk mengingat gambar dibandingkan dengan tulisan (Paivio \& Csapo, 1973). Sehingga foto-foto yang menunjukkan penampilan tubuh dari teman sebaya, selebritis, maupun orang yang tidak dikenal di Instagram diingat dengan mudah sehingga berpengaruh terhadap penilaian remaja terhadap tubuhnya. Informasi yang diperoleh dari media tersebut meningkatkan keinginan remaja untuk memperbaiki keadaan tubuhnya agar tampak lebih menarik.

Kategorisasi data penelitian pada variabel intensitas komunikasi di media sosial Instagram menunjukkan bahwa secara umum subjek penelitian berada pada kategori yang tinggi sebanyak 135 orang $(43,41 \%)$. Berdasarkan kategorisasi variabel citra tubuh ditunjukkan bahwa mayoritas subjek penelitian berada dalam kategori negatif sebanyak 136 orang $(43,73 \%)$, sehingga dapat dinyatakan bahwa mayoritas subjek penelitian memberikan penilaian terhadap tubuhnya secara negatif. Hasil tersebut membuktikan bahwa kedua variabel dalam penelitian ini memiliki arah yang negatif, semakin tinggi intensitas remaja perempuan berkomunikasi di media sosial Instagram maka mereka semakin negatif dalam memberikan penilaian terhadap tubuhnya.

Berdasarkan koefisien determinasi $\left(\mathrm{R}^{2}\right)$ diketahui bahwa kontribusi intensitas komunikasi di media sosial Instagram terhadap citra tubuh sebesar $22,4 \%$. Artinya prosentase sisanya sebesar $77,6 \%$ dipengaruhi oleh faktor lain yang tidak ada dalam penelitian ini. Sehingga hal tersebut menunjukkan bahwa citra tubuh tidak hanya dipengaruhi oleh faktor intensitas komunikasi di media sosial Instagram, namun juga oleh variabel-variabel lain seperti komentar orang tua, peran teman sebaya, dan faktor kognitif (Cash \& Smolak, 2011). Selain itu, media lainnya yang digunakan oleh subjek dalam kesehariannya untuk memperoleh informasi terkait tubuh, melalui media konvensional maupun modern, juga dapat memberikan pengaruh terhadap citra tubuh subjek pelajar perempuan di Denpasar.

Berikut beberapa penelitian mengenai variabel lain yang memiliki hubungan dengan citra tubuh selain intensitas komunikasi di media sosial Instagram, yakni penelitian yang dilakukan oleh Wiranatha dan Supriyadi (2015) mengenai hubungan citra tubuh dengan kepercayaan diri dengan jumlah responden sebanyak 492 siswi ditunjukkan bahwa adanya hubungan yang searah namun lemah antara citra tubuh dan kepercayaan diri $(r=0,350 ; \mathrm{p}<0,05)$ dengan sumbangan efektif variabel citra tubuh terhadap kepercayaan diri sebesar 12,2\%. Sunartio, Sukamto, dan Dianovinina (2012) dalam penelitiannya untuk mengetahui pengaruh social comparisons terhadap citra tubuh, dibuktikan bahwa semakin sering perempuan membandingkan bentuk tubuhnya dengan bentuk tubuh perempuan lain yang lebih menarik, maka semakin tinggi pula tingkat ketidakpuasan terhadap tubuh yang dialaminya. Penelitian yang dilakukan oleh Kenny, Keighran, Molcho, \& Kelly (2016) terhadap 111 responden berusia 13-18 tahun ditemukan bahwa teman sebaya memberikan pengaruh yang negatif terhadap citra tubuh remaja. 
Lingkungan teman sebaya mendorong remaja untuk berpenampilan sesuai dengan ekspektasi kelompok, apabila terdapat perbedaan maka akan menimbulkan hubungan negatif antara remaja dengan kelompoknya.

Terdapat beberapa keterbatasan dalam penelitian ini, berdasarkan pada faktor lain yang mempengaruhi serta kendala saat pelaksanaan penelitian. Pada penelitian ini, peneliti tidak mempertimbangkan faktor kepribadian subjek

penelitian, karena berdasarkan masing-masing tipe kepribadian memiliki intensitas yang berbeda dalam berkomunikasi di media sosial. Hal ini didasarkan pada penelitian yang dilakukan oleh Widiantari dan Herdiyanto (2013) yang membuktikan bahwa terdapat perbedaan intensitas komunikasi melalui media sosial pada tipe kepribadian ekstrovert dan introvert. Seseorang dengan tipe kepribadian ekstrovert cenderung untuk menilai keadaan fisik secara lebih positif dan lebih memperhatikan penampilan jika dibandingkan dengan tipe kepribadian introvert (Kvalem, Soest, Roald, \& Skolleborg, 2006).

Kendala lainnya yang dihadapi dalam penelitian ini adalah pada saat pengambilan data untuk uji coba skala penelitian, sekolah-sekolah di Denpasar sudah selesai melaksanakan ulangan umum, sehingga sedikit siswi yang masuk ke sekolah. Kelemahan lainnya yang terdapat dalam penelitian ini adalah peneliti tidak mempertimbangkan asal suku bangsa dari masing-masing subjek penelitian. Pada kenyataannya, subjek penelitian berasal dari berbagai suku bangsa, dengan mayoritas berasal dari suku bangsa Bali. Berdasarkan pada Cash dan Smolak (2011) ditunjukkan bahwa pada masing-masing budaya memiliki perbedaan mengenai tubuh yang ideal, hal tersebut dikarenakan masing-masing budaya memiliki cara tersendiri untuk memenuhi makanannya yang ditinjau dari akses mendapatkan makanan, ketersediaan makanan, faktor kesehatan, gender, serta perkembangan ekonomi.

Berdasarkan penelitian yang telah dilakukan, dapat ditarik kesimpulan bahwa intensitas komunikasi di media sosial Instagram berkontribusi terhadap citra tubuh remaja perempuan pelajar SMA Negeri di Denpasar. Intensitas komunikasi di media sosial Instagram yang tinggi dapat mengakibatkan penurunan citra tubuh remaja perempuan pelajar SMAN di Denpasar, citra tubuh remaja perempuan pelajar SMA Negeri di Denpasar tergolong rendah, dan intensitas remaja perempuan pelajar SMA Negeri di Denpasar dalam berkomunikasi di media sosial Instagram tergolong rendah.

Berdasarkan kesimpulan yang telah dipaparkan, maka peneliti dapat memberikan saran bagi peneliti selanjutnya, yaitu diharapkan mampu mempertimbangkan faktor kepribadian dan budaya dari masing-masing responden penelitian, mengantisipasi dengan mencari informasi mengenai kalender akademik dari masing-masing sekolah.
Apabila peneliti ingin mengembangkan penelitian terkait dampak media sosial dan citra tubuh, peneliti diharapkan untuk mempertimbangkan aktivitas dalam menggunakan media sosial Instagram secara lebih mengkhusus, seperti perbandingan terhadap foto di media sosial Instagram. Serta melakukan penelitian mengenai citra tubuh dengan variabelvariabel lain selain variabel yang telah diteliti karena masih terdapat $77,6 \%$ yang dapat berperan.

\section{DAFTAR PUSTAKA}

Azwar, S. (2015). Penyusunan skala psikologi. Yogyakarta: Pustaka Pelajar.

Banfield, S., \& McCabe, M.P. (2002). An evaluation of the construct of body image. Adolescence, 37(146), 373-393. Diakses tanggal 3 November 2017 dari https://ncbi.nlm.nih.gov.

Behan, E. (2015). Negative reflections - how social media affects body image satisfaction in irish females. (Naskah tidak dipublikasikan). Master of Science in Marketing, National College of Ireland, Dublin.

Berelson, B., \& Streiner, G.A. (1964). Human behavior: An inventory of scientific findings. New York: Harcourt, Brace, \& World.

Brahmini, I.A.B. (2017). Studi pendahuluan: Citra tubuh remaja perempuan pelajar sma negeri di kota denpasar yang menggunakan media sosial Instagram. (Naskah tidak dipublikasikan). Program Studi Psikologi, Fakultas Kedokteran, Universitas Udayana, Denpasar.

Brennan, M. L. (2010). Body image perceptions: Do gender differences exist?. Psi Chi Journal of Undergraduated Research, 15(3), 130-138. Diakses dari https://web.uvic.ca.

Cash, T. (2012). Encyclopedia of body image and human appearance. Oxford: Elsevier.

Cash, T. \& Smolak, L. (2011). Body image, a handbook of theory, research, and clinical practice edisi 2 . New York: The Guildford Publications.

Cash, T.F., \& Pruzinsky, T. (2002). Body image: A handbook of theory, research, and clinical practice. New York: Guildford Publications.

Cramer, S., \& Inkster, B. (2017). \#Status mind, social media and young people mental health's and well being. Royal Society for Public Health. Diakses 1 November 2017 dari https:// rsph.org.uk

Davidson, T.E., \& McCabe, M.P. (2006). Adolescent body image and psychological functioning. The Journal of Social Psychology, 146(1), 15-30. doi: 10.3200/SOCP.146.1.1530.

DeVito, J. (2009). Komunikasi antar manusia. Tangerang: Karisma Publishing Group.

Dewi, I. (2015). Pengantar psikologi media. Jakarta: Prestasi Pustaka.

Diandra. (2017, Januari 30). Bersama melawan berita palsu. Jakarta: Kementrian Komunikasi dan Informatika Republik Indonesia. Diakses dari https:// kominfo.go.id

Dittmar, H. (2009). How do "body perfect" ideals in the media have a negative impact on body image and behaviors? factors and processes related to self and identity. Journal of Social and Clinical Psychology, 28(1), 1-8. doi: 10.1521/jscp.2009.28.1.1.

Endersz, N., \& Pepin, G. (2015). Facebook, Instagram, Pinterest and co., citra tubuh and social media. Journal Eating Disorder, 3(1). doi: 10.1186/2050-2974-3-S1-O22. 


\section{I.A.B. BRAHMINI \& SUPRIYADI}

Fardouly, J. D., Diedrichs, P.C., Vartanian, L., \& Halliwel, E. (2015). Social comparisons on social media, the impact of Facebook on young women's citra tubuh concerns and mood. Body Image, 13, 38-45. doi: 10.1016/j.bodyim.2014.12.002.

Fardouly, J.D., Pinkus, R.T., Vartanian, L. (2017). The impact of appearance comparisons made through social media, traditional media, and in person in women's everyday lives. Body Image, 20, 31-39. doi: 10.1016/j.bodyim.2016.11.002

Field, A. (2009). Discovering statistics using SPSS. London: Sage Publication.

Ghozali, I. (2016). Aplikasi analisis multivariate dengan program IBM SPSS 23. Semarang: Badan Penerbit Universitas Diponegoro.

Grogan, S. (2008). Body image, understanding body dissatisfaction in men, women, and children. New York: Routledge.

Hurlock, E. B. (2002). Psikologi perkembangan, suatu pendekatan sepanjang rentang kehidupan. Jakarta: Erlangga.

Kementrian Hukum dan Hak Asasi Manusia Republik Indonesia. (2010). Pengelolaan Penyelenggaraan Pendidikan. Jakarta: Direktorat Jendral Peraturan Perundang-undangan. Diakses tanggal 3 November 2017 dari https:// ditjenpp.kemenkumham.go.id.

Kaplan, \& Haenlein,. (2010). Invited comment on the theme of the special issue social media: back to the roots and back to the future. Journal of Systems and Information Technology, 14(2), 101-104. doi: 10.1108/13287261211232126.

Kenny,U., Keighran, M., Molcho, M., \& Kelly, C. (2016). Peer influences on adolescent body image: friends or foes? Journal of Adolescent Research, 32(6), 768-799. doi: 10.1177/0743558416665478.

Kvalem, I.L., Soest, T., Roald H.E., \& Skolleborg, K.C. (2006). The interplay of personality and negative comments about appearance in predicting body image. Body Image, 3, 263273. doi: 10.1016/j.bodyim.2006.04.002.

Kleemans, M., Daalmans, S., Carbaat, I., \& Anschutz, D. (2016). Picture perfect: The direct effect of manipulated Instagram photos on body image in adolescent girls. Media Psychology, 21, 93-110. doi: 10.1080/15213269.2016.1257392.

Lerner, R.M., \& Steinberg, L. (2002). Handbook of adolescent psychology edisi 2. New Jersey: John Wiley \& Sons, Inc.

Lewallen, J., \& Morawitz, E.B. (2016) Pinterest or thinterest? Social comparisons and body image on social media. Social Media + Society, 1-9. doi: 10.1177/20563051166405509.

Mahardika, K. (2015). Pengaruh Instagram terhadap kehidupan remaja. Tulisan pada http://www.academia.edu.

Manago, A.M., Graham, M.B., Greenfield, P.M., \& Salimkhan, G. (2008). Self-presentation and gender on My-Space. Journal of Applied Developmental Psychology, 29, 446-458. doi:10.1016/j.appdev.2008.07.001.

Mayfield, A. (2008). What is social media?. California: iCrossing. Diakses dari http://www.icrossing.com.

Paivio, A., \& Csapo, K. (1973). Picture superiority in free recall: imagery or dual coding?. Cognitive Psychology, 5(2), 176206. doi: 10.1016/0010-0285(73)90032-7.

Papalia, D.E., Old, S.W., \& Feldman, R.D. (2011). Human Development. Jakarta: Kencana.

Perloff, R.M. (2014). Social media effects on young women's citra tubuh concerns, theoritical perspectives an an agenda for research. Sex Role, 71(11-12), 363-377. doi: 10.1007/s11199-014-0384-6.

Rudd, N.A. \& Lennon, S.J. (2000). Body image and appearance management in college woman. Clothing and Textiles Research Journal , 18(3), 152-162.

Said, A. (2015). Mendidik remaja nakal. Jakarta: Semesta Hikmah.

Santoso, S. (2014). Panduan lengkap SPSS versi 20. Jakarta: Elex Media Komputindo.

Santrock, J. (2007). Remaja. Jakarta: Erlangga.

Sarwono, S. (2015). Psikologi remaja. Jakarta: Raja Grafindo.

Smolak, L., \& Thompson, J.K. (2009). Body image, eating disorders, and obesity in youth, assesment, prevention, treatment. Washington DC: American Psychological Association.

Sunartio, L., Sukamto, M., Dianovinina, K. (2015). Social comparison dan body dissatisfaction pada wanita dewasa awal. Humanitas, 9, 157-168.

Taylor, S.E., Peplau, L.A., Sears, D.O. (2009). Psikologi sosial edisi 12. Kencana: Jakarta.

Tiggeman, M., \& Miller, J. (2010). The internet and adolescent girls weight satisfaction and drive for thinnes. Sex Roles , 63, 79-90. doi: 10.1007/s11199-010-9789-z.

Tiggeman, M. \& Slater, A. (2013). The internet and adolescent girls weight satistfaction and drive for thinnes. International Journal Eat Disorder, 46, 630-633. Doi: 10.1177/0272431613501083

Utami, A.M.V., Lestari, M.T., \& Putra, A. (2015). Pergeseran budaya komunikasi pada era media baru (studi etnografi virtual penggunaan LINE oleh digital natives).

E-Proceeding of Management, 2(3), 4042-4050.

Wertheim, E.M., \& Paxton, S.J. (2012). Body image development adolescent girls. In Cash, T.F. Encyclopedia of Body Image. Oxford: Elsevier.

Wiranatha, F.D., \& Supriyadi. (2015). Hubungan antara citra tubuh dengan kepercayaan diri pada remaja pelajar putri di Kota Denpasar. Journal Psikologi Udayana, 2(1), 38-47

Widiantari, K.S., \& Herdiyanto, Y.K. (2013). Perbedaan intensitas komunikasi melalui jejaring sosial antara tipe kepribadian ekstrovert dan introvert pada remaja. Jurnal Psikologi Udayana, 1(1), 106-115. 


\section{LAMPIRAN}

Tabel 1

Deskripsi Statistik Data Penelitian

\begin{tabular}{ccc}
\hline Deskripsi Data & $\begin{array}{c}\text { Intensitas Komunikasi di } \\
\text { Media Sosial Instagram }\end{array}$ & Citra Tubuh \\
\hline $\mathrm{N}$ & 311 & 311 \\
Mean Teoretis & 75 & 80 \\
Mean Empiris & 72,91 & 75,00 \\
SD Teoretis & 15 & 16 \\
SD Empiris & 8,584 & 8,537 \\
Xmin & 48 & 46 \\
Xmax & 102 & 110 \\
Sebaran Teoretis & $30-120$ & $32-128$ \\
Sebaran Empiris & $48-102$ & $46-110$ \\
$\mathrm{t}$ & $-4,287$ & $-10,336$ \\
\hline
\end{tabular}

Tabel 2

Uji Normalitas Data Penelitian

\begin{tabular}{cccc}
\hline Variabel & Kolmogorov-Smirnov & $\begin{array}{c}\text { Asymp. Sig. (2-tailed) } \\
(\mathrm{p})\end{array}$ & Keterangan \\
\hline $\begin{array}{c}\text { Intensitas Komunikasi di } \\
\text { Media Sosial Instagram }\end{array}$ & 1,011 & 0,258 & Data Normal \\
Citra Tubuh & 1,232 & 0,096 & Data Normal \\
\hline
\end{tabular}

Tabel 3

Hasil Besaran Sumbangan Intensitas Komunikasi di Media Sosial Instagram, DFFIT, dan Citra Tubuh

\begin{tabular}{ccccc}
\hline \multicolumn{5}{c}{ Model Summary $^{b}$} \\
\hline Model & R & R Square & Adjusted R Square & Std.Error of the Estimate \\
\hline 1 & 0.856 & 0.733 & 0.731 & 4.428 \\
\hline
\end{tabular}


Tabel 4

Hasil Uji Regresi Sederhana

\begin{tabular}{ccccccc}
\hline & & \multicolumn{5}{c}{ ANOVA } \\
\hline & Model & Sum of & Df & Mean Squares & F & Sig. \\
& & Squares & & & & \\
\hline 1 & Regression & 5057,600 & 1 & 5057,600 & 89,133 & $0,000^{\mathrm{a}}$ \\
& Residual & 17533,397 & 309 & 56,742 & & \\
& Total & 22590,997 & 310 & & & \\
\hline
\end{tabular}

Tabel 5

Besaran Peran Variabel Bebas Terhadap Variabel Tergantung

\begin{tabular}{ccccc}
\hline \multicolumn{5}{c}{ Model Summary $^{b}$} \\
\hline Model & R & R Square & Adjusted R Square & Std.Error of the Estimate \\
\hline 1 & 0.473 & 0.224 & 0.221 & 7.533 \\
\hline
\end{tabular}

Tabel 6

Hasil Uji Signifikansi Parameter Intensitas Komunikasi di Media Sosial Instagram dan Citra Tubuh

\begin{tabular}{ccccccc}
\hline \multicolumn{7}{c}{ Coefficients $^{2}$} \\
& \multirow{7}{c}{$\begin{array}{c}\text { Unstandardized } \\
\text { Coefficients }\end{array}$} & $\begin{array}{c}\text { Standardized } \\
\text { Coefficients }\end{array}$ \\
\cline { 3 - 7 } & Model & B & Std. Error & Beta & T & Sig. \\
\hline 1 & (Constant) & 40,690 & 3,659 & & 11,121 & 0,000 \\
& IK & $-0,471$ & 0,050 & $-0,473$ & $-9,441$ & 0,000 \\
\hline
\end{tabular}

a. Dependent Variable: Citra Tubuh

Tabel 7

Rangkuman Hasil Uji Hipotesis Penelitian

\section{Hipotesis}

Intensitas komunikasi di media sosial Instagram berkontribusi terhadap citra tubuh remaja perempuan pelajar SMA Negeri di Denpasar 